Anthropos: Jurnal Antropologi Sosial dan Budaya (Journal of Social and Cultural Anthropology) 6 (1) (2020): 52-61

DOI: 10.24114 /antro.v6i1.16634

Anthropos: Jurnal Antropologi Sosial dan Budaya (Journal of Social and Cultural Anthropology)

Available online http://iurnal.unimed.ac.id/2012/index.php/anthropos

\title{
Permainan Tradisonal Budaya Martumba sebagai Media Pendidikan Karakter bagi Anak di Batak Toba
}

\section{Traditional Game of Martumba Culture as a Character Education Media for Children in Toba Batak}

Friska Aritonang 1) Iky Sumarthita Putri Prayitno ${ }^{2)}$ \& Yurulina Gulo ${ }^{3)}$

1) Magister Sosiologi Agama, Fakultas Teologi, Universitas Kristen Satya Wacana

2) Dosen Fakultas Teologi, Universitas Kristen Satya Wacana

3) Alumni Magister Sosiologi Agama, Fakultas Teologi Universitas Kristen Satya Wacana Diterima: 20 Januari 2020; Disetujui:04 Maret 2020; Dipublikasi:01 Juni 2020;

\begin{abstract}
Abstak
Tulisan ini bertujuan untuk mengetahui pengaruh permainan tradisional martumba terhadap pendidikan karakter anak. Martumba adalah sebuah permainan tradisional sambil menari. Pada mulanya martumba dilakukan pada malam hari di alaman (halaman) pada saat poltak bulan (bulan purnama), tarian ini dimainkan oleh orang dewasa, dimana laki-laki saling menyindir menggambarkan perkenalan pemuda batak Toba pada zaman dahulu kepada perempuan yang disukainya. Tetapi seiring dengan perkembangan zaman maka permainan ini tidak lagi dilakukan pada malam hari tetapi sesuai dengan konteks kegiatan dan para pemainnya bukan lagi orang dewasa tetapi anak-anak dan remaja. Mengingat bahwa anak-anak adalah media yang tepat dalam mempertahankan budaya dizaman modern sekarang ini. Tulisan ini menggunakan metode penelitian kualitatif dengan pendekatan deskriptif kualitatif terhadap anak di Batak Toba melalui teori memori budaya dan kajian ini menyimpulkan bahwa permainan Tradisional Martumba memiliki pengaruh terhadap perkembangan karakter anak karena permainan tersebut dapat dijadikan sebagai media ajar bagi anak sebab didalamnya terdapat kegiatan untuk mendidik karakter anak yang disiplin, komunikatif, bekerjasama dengan kelompok, pengamatan dan sebagai sarana interaksi hubungan antar manusia sehingga kreativitas anak akan muncul melalui gerakan dan menginterpretasi lagu terhadap pesan yang akan disampaikan melalui nyanyian dan gerakan dalam permainan.
\end{abstract}

Kata Kunci: Martumba, Anak, Pendidikan karakter

\begin{abstract}
This paper aims to determine the effect of traditional Martumba games on children's character education. Martumba is a traditional game while dancing. Martumba was originally performed at night in page during the poltak of the moon, this dance is played adults, where men insinuate each other describing the introduction of the Toba Batak youth in ancient times to the woman he liked. But along with times, this game is no longer done at night but in accordance with the context of the activity and the players are no longer adults but children and adolescents. Given that children are the right media in maintaining the culture of the modern era. This paper uses a qualitative research method with a qualitative descriptive approach to children in Batak Toba through cultural memory theory and this study concludes that the Martumba Traditional game has an influence on children's character development because the game can be used as a teaching medium for children because in it there are activities to educate characters children who are disciplined, communicative, cooperate with groups, observations and as a means of interaction between humans so that children's creativity will emerge through movements and interpret songs to the message to be conveyed through song and movement in the game.
\end{abstract}

Keywords: Martumba, Children, Character education

How to Cite: Aritonang, F., Prayitno, I.S.P., \& Gulo, Y. (2020). Permaianan Tradisonal Budaya Martumba Sebagai Media Pendidikan Karakter Bagi Anak di Batak Toba Anthropos: Jurnal Antropologi Sosial dan Budaya (Journal of Social and Cultural Anthropology) 6 (1): 52-61.

*Corresponding author: ISSN 2460-4585 (Print)

E-mail: friskaarios@gmail.com ISSN 2460-4593 (Online) 


\section{PENDAHULUAN}

Budaya berasal dari bahasa Sansekerta yaitu buddhayah bentuk jamak dari kata buddhi artinya akal atau budi. E.B Taylor mendefenisikan kebudayaan adalah sebuah kompleks yang mencakup pengetahun, keyakinan, kesenian, moral, hukum, adat istiadat, kemampuan serta kebiasaan yang didapatkan oleh manusia sebagai anggota masyarakat. Kebudayaan adalah segala hal yang tercermin dalam realitas apa adanya di masyarakat yang dikembangkan di berbagai daerah, khususnya Indonesia yang memiliki beragam kebudayaan (Setia \& Sulasman, 2013).

Kebudayaan terdiri dari beberapa aspek, salah satu diantaranya adalah kesenian. Salah satu etnis yang berada di daerah Batak Toba mempunyai beberapa kesenian, diantaranya tarian martumba. Pada awalnya martumba dikembangkan oleh seorang seniman Batak dan akhirnya semua daerah mengenal dengan tumba. Pada masa itu martumba diyakini sebagai ritus atau media komunikasi (doa) yang ditujukan kepada Ommputa Mula Jadi Na Bolon untuk meminta berkat (Pasu-Pasu) (Elita, 2016). Kegiatan ini dilakukan oleh masyarakat Batak Toba sebagai rasa penghormatan dan ikatan kekeluargaan yang kuat kepada sesamanya. Martumba juga sebagai sebuah permainan yang dilakukan bernyanyi sambil menari berisi pantun bersahut-sahutan sebagai sarana untuk mengekspresikan dan sebagai alat komunikasi yang efektif dalam mengungkapkan pesan yang melambangkan perjuangan, semangat, permohonan dan ungkapan hati. Komunikasi adalah sebuah pertukaran ide, pesan, dan kontak serta interkasi sosial termasuk aktivitas pokok dalam kehidupan manusia (Rita, 14 Oktober 2019). Melalui komunikasi manusia bisa mengenal antara satu dengan yang lain, menjalin hubungan, membina kerjasama, saling mempengaruhi, bertukar ide dan pendapat, serta mengembangkan suatu masyarakat dan budaya. Komunikasi sebagai alat yang penting bagi kehidupan manusia dan manusia yang tidak berkomunikasi akan sulit sekali untuk berkembang dan bertahan. Komunikasi menekankan kesamaan atau kebersamaan. komunitas adalah sekelompok orang yang berkumpul atau hidup bersama untuk mencapai tujuan tertentu dan mereka berbagai makna dan sikap. Tanpa komunikasi tidak aka ada komunitas dan tanpa komunitas tidak aka nada berlangsung komunikasi. Komunikasi adalah suatu proses dan tindakan manusia dalam suatu kelompok masyarakat dan masyarakat membutuhkan komunikasi sebagai penguat struktur mereka.

Komunikasi

menggambarkan bagaimana seseorang menyampaikan suatu pesan/infromasi lewat simbolsimbol atau verbal dan nonverbal kepada orang lain sehingga si penerima pesan/informasi menafsirkan pesan tersebut sehingga terjadi perubahan pengetahuan, sikap, dan keterampilan sesuai dengan tujuan dan maksud si pengirim pesan (Nofrion, 2016). Komunikasi adalah paket isyarat yang melibatkan pesan verbal, isyarat tubuh ataupun kombinasi dari keduanya (Evi, 2019). Dalam tarian tumba sebagai alat komunikasi yang efektif dalam memberikan pesan-pesan melalui gerekan bahasa isyarat lewat tarian dan juga nyanyian. Pesan-pesan moralpun terkandung di dalamnya dengan tujuan kebersamaan dalam suatu komunitas dalam mencapai tujuan dan makna hidup yang capai.

Martumba pertama sekali dikembangkan di Tapanuli Utara (Pesisir Sibolga), kehadiran tarian martumba ini hingga ke berbagai daerah di tanah Batak dibawa oleh masyarakat etnis Batak Toba yang berpindah dan kemudian melestarikan tarian martumba secara turun temurun sebagai sebuah hiburan pada masa itu. Tarian martumba muncul sekitar tahun 1940-an ditarikan oleh 
pemuda-pemudi dengan nyanyian berupa pantun (berbalas pantun) pada malam hari saat terang bulan sebagai media hiburan untuk menyambut para pejuang melawan penjajah sebagai ungkapan rasa hormat dan syukur. Tarian ini di tampilkan di depan halaman rumah dengan pola bentuk lingkaran, gerakan sombah, bertepuk tangan, melompat, mengangkat kaki. Pada umumnya syair dari martumba ini berisi (ummpasa-ummpasa) pantun berkesan religius atau kata-kata bijak menekankan hal-hal spiritual tentang karunia dan rahmat (Elita, 2016).

Fungsi sosial martumba adalah salah satu pola pembentukan kehidupan dalam masyarakat untuk menjalin kekompakan dan berelasi baik bagi anak-anak dan membangun komunikasi. Rudolf $F$. Verderber mengemukakan bahwa komunikasi dalam fungsi sosial yakni untuk menunjukkan kesenangan, menunjukkan ikatan dengan orang lain, membangun dan memelihara hubungan. Adapun Judy C. Pearson mengutarakan bahwa fungsi komunikasi untuk kelangsungan hidup masyarakat, lebih tepatnya untuk memperbaiki hubungan sosial dan mengambangkan keberadaan suatu masyarakat. Selain itu dapat juga digunakan untuk menyosialisasikan norma-norma dan budaya pada generasi selanjutnya baik dalam pengetahuan, keyakinan, keterampilan, nilai-nilai, norma budaya (Nofrion, 2016). Dengan demikian tarian martumba sebagai suatu daya seni kearifan lokal dari suku batak dan juga alat komunikasi untuk menyampaikan pesan melalui nyanyian dan gerakan dalam menunjukkan eksistensi kearifal lokal dari suku Batak untuk memupuk hubungan, nilai kebersamaan. (Marlon, 8 Oktober 2019).

Hingga saat ini perkembangan martumba semakin pesat, gereja dan sekolah telah mengikutsertakan anak-anak dalam tarian martumba yang digunakan saat perayaan-perayaan hari besar dalam gereja, untuk menyambut tamu, mengenang sejarah pahlawan melalui kegiatan kemerdekaan pada 17 Agustus serta mengungkapkan kecintaan terhadap lingkungan. Gereja dan sekolah melihat kegiatan itu sangat bagus sehingga anakanak ikut berperan aktif dan tidak jarang tarian tumba ini dilakukan sebagai kegitaan perlombaan bagi anak-anak karena bersifat membangun karakter dan kreativitas anak (Jesika, 12 Oktober 2019). Maka dari itu untuk mengetahui lebih dalam lagi penulis tertarik untuk meneliti tentang "Permainan Tradisional Budaya Martumba Sebagai Media Pendidikan Karakter Bagi Anak Batak Toba".

\section{METODE PENELITIAN}

Metode penelitian yang digunakan adalah metode penelitian kualitatif dengan pendekatan deskriptif kualitatif dimana peneliti menggunakan penelitian lapangan (field research). Tujuan dari penelitian kualitatif yaitu menggambarkan dan mengungkapkan (to describe and explore) dan menggambarkan dan menjelaskan (to describe and explain). Menurut Erikson menyatakan bahwa penelitian kualitatif berusaha untuk menemukan dan menggambarkan secara naratif kegiatan yang dilakukan dan pengaruh dari tindakan yang dilakukan terhadap kehidupan mereka (Albi \& Setiawan, 2018). Penelitian kualitatif dilakukan dengan karakteristik yang mendeskripsikan suatu keadaan yang sebenarnya atau fakta, untuk itu peneliti harus mendeskripsikan suatu objek atau fenomena yang dituangkan dalam tulisan yang bersifat naratif. Dalam penulisan penelitian kualitatif berisi kutipan data yang diungkap di lapangan untuk memberikan dukungan terhadap apa yang disajikan dalam laporannya. Jadi, dengan pendekatan kualitatif- deskriptif ini peneliti mengkaji literature yang ada dan mengumpulkan data-data yang sesuai berdasarkan tujuan penelitian dari masyarakat Batak Toba. 
Adapun data yang diperoleh dari penelitian di lapangan menggunakan teknik wawancara dan pengumpulan data serta melakukan pengamatan terhadap kegiatan yang dilakukan anak-anak masyarakat Batak Toba dalam mengikuti kegiatan martumba dalam melestarikan dan mewariskan kebudayaan batak Toba. Untuk itu dalam penelitian kualitatif ini juga menggunakan teori untuk mendukung hasil penelitian, menurut Silverman mengatakan teori merupakan sumber tenaga bagi penelitian, dimana sesuai dengan perkembangan zaman teori dikembangkan dan dimodifikasi. Teori adalah sarana pokok untuk menyatakan hubungan sistematis pada fenomena yang diteliti sehingga teori memberikan batasan terhadap ilmu dengan cara memperkecil jangkauan dari fakta yang akan dipelajari (Albi \& Setiawan, 2018).

Selain field research dilakukan juga studi pustaka (library research) untuk menambah literatur yang lebih relevan dengan penelitian yang dilakukan. Literatur tersebut berupa buku, jurnal, artikel dan dan tulisan ilmiah lainnya. Informan yang akan diwawancarai yakni informan kunci (seniman budaya Batak) dan informan penting (pengajar martumba dan pemain martumba). Dalam penelitian kualitatif menurut Nasution (2003) mengatakan bahwa tidak ada pilihan lain dari pada menjadikan manusia menjadikan manusia sebagai instrument penelitian utama. Setelah melakukan penelitian, peneliti akan melakukan analisis data. Menurut Stainback (1998) analisis data merupakan hal kritis dalam penelitian kualitatif, sehingga hipotesis dapat dikembangkan dan dan dievaluasi (Albi \& Setiawan, 2018). Hasil dari analisis data dan dari proses penelitian ini nantinya akan berupa gambaran deskriptif mengenai gambaran permainan tradisonal budaya Martumba terhadap perkembangan karekter yang berguna dan mendidik terhadap anak suku Batak Toba.
Memori adalah kapasitas untuk mengingat untuk menciptakan kembali masa lalu kita. Memori budaya memberikan defenisi sebagai dimensi di luar manusia. Ingatan budaya adalah proses dimana masyarakat menjamin kelangsungan budaya dengan melestarikan budaya tersebut melalui pengetahun keloktif dari satu generasi ke generasi berikutnya dan memungkinkan kepada generasi selanjutnya untuk merekonstruksi identitas budaya mereka. Defenisi budaya mengalir dari pemahaman dengan ide pengembangan yang unik termasuk dalam bahasa, organisasi politik, serta ritual dan upacara. Makna yang dianggap biasa saja tetapi bagi manusia sebagai pemikul simbol dalam evolusioner memberikan peran emosi menjadi elemen yang penting, dorongan emosi muncul saat mengenang peristiwa-peristiwa pada masa lampau dalam kegiatan ritual diisi dengan komposisi simbolis dan terus diulang, seseorang akan mengamati siklus hidup baru setiap tahunnya, sebagai sebuah kemampuan manusia untuk menerjemahkan pengalaman rasa kagum, heran dan hormat, memberi sekelompok manusia mengarah pada konfigurasi budaya makna yang di wariskan dari generasi ke generasi (Rodriguez, 2007).

Masyarakat Batak Toba Merupakan suku yang hidup dalam dengan adat dan memiliki tradisi-tradisi dalam kebudayaan, salah satunya adalah budaya permainan tradisional martumba. Martumba menyimpan kekuatan semesta Alam, ritual menghubungkan dengan leluhur, memadiasi dan memperkuat kemampuan manusia dan membawa komunitas dalam memperkuat solidaritas dengan mempengaruhi prilaku lewat pendidikan karakter melalui tradisi suku Batak Toba budaya Martumba. Charles Davis mengatakan tradisi adalah cara menanggapi kenyataan, termasuk perasaan, ingatan, gambar, ide, sikap, hubungan personal atau dirangkai menjadi seluruh kompleks yang membentuk 
kehidupan dalam dunia tertentu atau dunia dibatasi oleh cakrawala yang menentukan arti tertentu dari kenyataan, kata tradisi dapat dilihat sebagai suatu partisipatif, mengingat kata benda atau memori adalah bentuk tertentu dari tindakan. Dua eleman yang ditemukan dalam memori budaya, yaitu keduanya mengingat dan satu sisi anggota budaya adalah tradition. Segala sesuatu yang diingat atau ditimbulkan dalam perasaan atau afektivitas, cara bertindak, bentuk bahasa, asporasi, berhubungan dengan interpersonal. Warisan proses kreatif menjadi akun manusia yang unik bahwa budaya membangun diri mereka sendiri untuk memahami realitas dan meneruskan dari generasi ke generasi melalui bahasa itulah memori penting yang mentransmisikan pesan berdasarkan emosi. Melalui memori budaya permainan tradisional martumba dapat ditransmisikan sebagai pendidikan karakter bagi anak untuk melanjutkan kembali tradisi suku Batak Toba dari generasi ke generasi.

\section{HASIL DAN PEMBAHASAN Fungsi Martumba}

Tortor martumba sebagai sarana upacara persembahan dan pemujaan yang dilakukan oleh leluhur dahulu pada masyarakat Batak Toba, khususnya ritual mangido udan meminta hujan) kepada Mula Jadi Nabolon atau sang pencipta. Tortor martumba di gunakan sebagai pertunjukan event besar seperti festival di sekolah pada saat perlombaan hari kemerdekaan Indonesia dengan tujuan untuk menjaga warisan budaya agar tidak pudan serta mencintai budaya sendiri di mana pada kemajuan zaman yang berkembang saat ini menyebabkan kesenian daerah hampir punah. Tortor martumba juga sebagai sarana hiburan yang dilakukan oleh masyarakat setempat untuk menampilkan nilai-nilai kebersamaan, kekompakan dan kekeluargaan (Elita, 2016).
Permianan tradisional tor-tor martumba ini memiliki keunikan karena tarian ini dilakukan sambil bernyanyi dan lagu yang dinyanyikan adalah pantun (umpasa). Dalam setiap pantun yang dinyanyikan memiliki makna tersendiri yang disampaikan pada anak-anak maupun juga kepada penonton.

Tumba ini memiliki fungsi sebagai hiburan bagi masyarakat, untuk belajar adat, mencari jodoh, melatih kerja sama juga sebagai alat untuk mendidik. Agar tidak hilang begitu saja ditelan zaman (Prayetty, 2016). Pada mulanya martumba dilakukan pada malam hari di alaman (halaman) pada saat poltak bulan (bulan purnama), tarian ini dimainkan oleh orang dewasa danlaki-laki saling menyindir mengambarkan perkenalan pemuda batak Toba pada zaman dahulu kepada perempuan yang disukainya. Tetapi seiring dengan perkembangan zaman karena dipengaruhi dengan kebiasaan dan pembaharuan setiap waktu permainan tradisional martumba ini tidak lagi dilakukan pada malam hari tetapi sesuai dengan konteks kegiatan seperti pada pagi hari atau siang hari dan para pelakunya bukan lagi orang dewasa tetapi anak-anak dan remaja. Mengingat bahwa anak-anak adalah media yang tepat dalam mempertahankan budaya di zaman modern sekarang ini (Gusti, 2016).

\section{Pembentukan Karakter melalui Permainan Tradisional Martumba}

Karakter anak merupakan hasil dari suatu pendidikan secara umum baik informal yang berlangsung dengan pembiasaan hal-hal yang baik, dalam etika, budaya, sedangkan pendidikan non formal yang berlangsung dalam masyarakat dalam bentuk pelatihan-pelatihan, kursus dan kerja sosial maupun pendidikan formal yang berlangsung di sekolah. Pendidikan merupakan usaha sadar untuk mempengaruhi peserta didik dalam menggembangkan dan mengaktualisasikan potensi yang ada pada dirinya, maka dari 
itu lewat aktivitas bermain akan merangsang potensi yang dimiliki anak (Bandi, 2011).

Pendidikan karakter merupakan bagian penting dalam dunia pendidikan, salah satu cara membentuk karakter dengan cara mengenalkan lagu-lagu anak dengan bermuatan positif dan pesan moral terkandung didalamnya. Nilai moral yang disisipkan dalam lirik lagu anak-anak ini dimaksudkan untuk mendidik perkambangan psikologi seorang anak (Kusumawati, 2013).

Permainan tradisional merupakan kekayaan bangsa yang mempunyai nilainilai luhur yang dapat diwariskan kepada anak-anak dan generasi penerus sebagai bagian dari kekayaan lokal yang seharusnya dimanfaatkan dalam proses pendidikan. Permainan lewat tarian yang diajarkan oleh nenek moyang kita merupakan warisan budaya yang harus dijaga, dilindungi dan dilestarikan.

Dalam menciptakan permainan tradisional nenek kita bukan sekedar menciptakan saja tetapi dibalik penciptaanya itu tersimpan makna yang dapat membantu menumbuhkan karakter anak, secara tidak langsung lewat tarian martumba sebagai permainan tradisional secara langsung dan tidak langsung akan melahirkan kepekaan terhadap semua input yang masuk pada anak yang tentunya memiliki pengaruh besar untuk menumbuhkan karakter anak. Dalam budaya mertumba tersebut terdapat makna luhur yang terkandung didalamnya, seperti nilai pendidikan, nilai agama dan nilai estetika yang yang nantinya bermanfaat dalam kehidupan bermasyarakat (Rosidatun, 2018).

Manfaat melalui kebudayaan tortor martumba yang ada di daerah batak toba akan menanamkan sikap, prilaku dan keterampilan kepada anak.

Ada delapan belas nilai karakter yang berasal dari nilai-nilai luhur universal yaitu, 1. nilai religius, 2. Jujur, 3. Toleransi, 4. Disiplin, 5. Kerjakeras, 6. Kreatif, 7.
Mandiri, 8. Demokratis, 9. Rasa ingin tahu, 10. Semangat kebangsaan, 11. Cinta tanah air, 12. Menghargai prestasi, 13. Bersahabat/ komunikatif, 14. Cinta damai, 15. Gemar membaca, 16. Peduli lingkungan, $17 . \quad$ Peduli sosial, 18. Tanggungjawab (Rosidatun, 2018). Bagi anak bermain merupakan refleksi pembebasan jiwa dan keterikatan dari aturan orangtua, bebas berekspresi. Pada saat memainkan tarian tor-tor martumba mengungungkapkan berbagai cerita hati, keceriaan jiwa, dan kegembiraan sekaligus menanamkan kebiasan berinterasi bersama anak-anak lainnya sehingga anak dapat belajar bergaul, bersosialisasi, mendapat pengalaman lingkungan sebagai proses perkembangan diri karena lewat permainan menjadi dapat menjadi proses untuk belajar.

\section{Martumba sebagai Media Pendidikan Anak}

Pada dasarnya dari berbagai teori perkembangan dapat di simpulkan bahwa masa anak adalah masa identik dengan permainan, melalui permainan tersebut memiliki peran penting dalam belajar. Dalam hal ini memberi kesempatan kepada anak untuk memahami, meresapi dan memberi arti terhadap apa yang mereka peroleh lewat permainan yang mereka ikuti. Selain itu, dapat memfasilitasi anak dalam beraktifitas fisik meliputi kegiatan berolahraga.

Melalui permainan tradisional martumba sebagai sarana menumbuhkan kemampuan bersosialisasi, sebagai proses interaksi dengan lingkungannya serta mengajar anak untuk menghargai orang lain, lewat kegiatan tersebut anak juga akan belajar mengurangi egosentrisnya karena berusaha bersaing dengan jujur (Nur, H., 2013). Dunia anak sering diidentifikasikan dengan dunia belajar dan bermain, bermain adalah suatu masa yang membahagiakan bagi anak. Dari bermaian terbentuk proses sosialisasi secara dini. Sebab dalam bermain anak belajar 
mengenal nilai-nilai budaya dan normanorman sosial yang yang diperlukan sebagai pedoman sosial (Ernawati, 2016).

Kegunaan permainan tradisional martumba di dalam pendidikan anak sebagai materi pembelajaran di sekolah yang bermanfaat sebagai penembah keterampilan khusus bagi siswa dalam memperlajari lagu daerah dan tari. Manfaat mempelajari martumba bagi anak-anak adalah sebagai media hiburan dan sebagai pertunjukan yang ditampilkan dengan persiapan yang baik. Selain itu tortor martumba juga bermanfaat sebagai hiburan bagi masyarakat dan memiliki makna kekeluargaa karena gerakan yang ditampilkan adalah gerakan berpengangan dan bergenggaman sehingga terlihat kekompoakan dan kerjasama yang baik.

Menurut Anindita Nayang anak belajar melalui panca indra ketika semakin banyak panca indra dilibatkan maka akan semakin mudah anak menerima informasi, selain itu anak juga belajar melalui bahasa. Anak diberikan kesempatan untuk berinterpretasi untuk mengungkapkan perasaanya. Pada simulasi tarian martumba terdapat gerakan, syair, musik yang memudahkan untuk mengingat dan memahami infromasi yang disampaikan tarian ini yang melibatkan responden. Berdasarkan penelitian yang dilakukan oleh Ervi Rachma Dewi, tentang pengaruh Tarian Tepung Selaci Puput terhadap peningkatan pengetahuan siswa Sekolah Dasar, dengan metode tari memungkinkan siswa secara aktif mengembangkan kemampuannya untuk belajar, lebih nyata dan lebih mandiri (Lia, R., Sinaga, V., dkk., 2019). Maka dari itu tarian martumba sebagai media pendidikan dapat mengambangkan minat, kreativitas dan kemampuan anak sebagai media untuk mengolah pikir, mengolah rasa, mengolah hati dan mengolah raga.

Bentuk penyajian sehingga dapat dijadikan media pendidikan bagi anak adalah dari gerakan yang dilakukan tidak berubah dari dahulu sampai sekarang, yang membedakan hanyalah syair atau pesan yang disampaikan sesuai dengan kegiatan yang sedang dilakukan. Martumba dinyanyikan oleh penari dan gerakan yang ada pada permainan tradisonal Martumba sangat sederhana yaitu somba adat, somba adat marhaliang, tangan martoppak dohot mangakkat pat marganti-ganti, manggatukkon tangan tu siamun tu hambirang dohot pat mangalakka, marsitiopan tangan, manggomgom tangan tu jolo, somba raja, singgang. Gerakan yang dilakukan secara serentak dan berirama sesuai dengan syair pantun yang dinyanyikan (Elita, 2016).

$$
\text { Dalam penyajian pakaian }
$$

melambangkan agar merawat budaya dari sudut pakaiaan adat melalui memakai kain ulos. Ulos adalah kain tenun khas batak, yang berarti secara harafiah selimut yang dapat mengahangatkan tubuh, melindungi dari terpaan udara dingin. Ulos dapat berfungsi dalam beberapa hal sebagai fungsi sandangan, sebagai selendang, sarung, penutup kepala dan lain sebagainya. Ulos dianggap sebagai sesuatu peninggalan leluhur orang Batak, yang merupakan bangsa yang hidup di datarandataran tinggi. Maka maksud pertama untuk memakai ulos agar menjaga tetap hangat, dan kain ulos dapat dikenakan untuk menghalau dingin selama sedang beraktivitas.

\section{Martumba sebagai Pengembangan Karakter Anak}

Pengembangan karakter anak melalui budaya martumba dapat diterapkan melalui dorongan dengan memberikan pujian yang efektif ketika anak-anak mampu menguasai tor-tor martumba dengan menjalin relasi bersama dengan anak-anak lainnya. Nilai tanggungjawab pribadi melalui kedisiplinan. kedisiplinan memotivasi orang untuk melakukan apa yang ia lakukan, hal tersebut di dasarkan pada tanggungjawab dalam aspek kehidupan. Disiplin diri adalah instruksi pribadi yang diberikan dan diterima oleh 
disiplin itu sendiri. Kedisiplinan diri menuntut prioritas, pengaturan, bertahan atas suatu pilihan atau kontrol diri. kedisiplinan adalah suatu perhatian dan tujuan hidup, baik dalam bidang pendidikan, olahraga, musik dan bisnis atau hubungan antar pribadi.

Melalui disiplin dapat membangun kebiasaan baik seseorang, dengan meningkatkan kemampuannya dalam bertahan. Membangun hubungan antarpribadi, meningkatkan stabilitas dan keteraturan kelompok didalam kelas, keluarga dan masyarakat. Lingkungan belajar bagi anak menjadi lebih produktif ketika anak dilatih disiplin saat mereka mendengar dan komunikasi satu sama lain. Dengan disiplin anak-anak akan hidup dalam keteraturan indikasi dari disiplin adalah keteraturan. keteraturan adalah bukti ketika seseorang mempertahankan lingkungaannya berada. Anak dapat melakukan kegiatan tersendiri tanpa harus diawasi meskipun guru atau pengajar sedang tidak didalam ruangan. Fungsi dari pengajaran kedisipilinan terhadap anak, pertama, nilai kerajinan dan nilai kebijaksanaan, akan memperlihatkan kedisiplinan dengan tepat waktu. Kedua, pintar. Orang yang menunjukkan kedisiplinan menggunakan berbagai sumber untuk mengerjakan pekerjaanya dengan memperoleh banyak pengetahuan. Anak-anak akan menunjukkan kedisiplinan ketika mereka mendapat persetujuan untuk merangkai akal mereka dan bekerja bersama dalam tugas yang besar yang tidak mungkin dikerjakan secara sendirian (Garmo, 2013).

Perkembangan dan pertumbuhan anak penting dijadikan perhatian khusus sebab proses berkembang dan bertumbuh anak akan mempengaruhi kehidupan mereka pada masa dewasa nanti. Setiap anak berkembang melalui proses yang terjadi secara bertahap, setiap perkembangan anak juga berbeda dengan satu sama lain sehingga harus memperhatikan bagaimana cara memberi didikan kepada mereka. Perkembangan anak bisa dipelajari dari perubahan pekembangan yang mencakup seluruh rentang kehidupan dari pembuahan sampai pada akhirnya. Perkembangan serangkaian perubahan progesif yang terjadi akibat proses kematangan dan pengalaman. Seperti yang dikatakan Van Den Daele, perkembangan berarti perubahan secara kualitatif, ini berarti bahwa perkembangan bukan sekedar penambahan seberapa sentimeter pada tinggi badan seseorang atau peningkatan kemampuan seseorang, melainkan suatu proses integrasi dari banyak struktur dan fungsi yang kompleks.

Perkembangan anak membutuhkan bantuan orang dewasa dalam memberikan kebutuhan anak tersebut. Jika tidak ada bantuan dari orang dewasa dalam memenuhi kebutuhannya maka anak tersebut dipastikan tidak berkembang. Orangtua merupakan orang pertama dalam memenuhi kebutuhan anak. Namun selanjutnya perkembangan anak tidak cukup sampai disitu saja, anak harus dibantu oleh lingkungan sekitar, bisa dilihat dari lembaga pendidikan, dan gereja untuk membentuk kepribadian anak tersebut. Harus disadari bahwa kajian pendidikan karakter dan budaya bangsa membawa nuansa baru dalam mengembangkan khazanah keilmuan sekaligus merupakan bidang kajian yang bersifat aplikatif-produktif dalam mengembangkan kepribadian perserta didik. Dikatakan aplikatif karena pendidikan karakter langusung mengarah pada penerapan dengan maksud untuk membangun karakter anak bangsa yang berkepribadian luhur serta dikatakan produktif karena proses pendidikan karakter dimaksudkan untuk menciptakan dan mengembangkan anak-anak Indonesia yang cerdas, aktif, berperadaban yang berlangsung secara terus menerus.

Pendidikan karakter (character education) adalah gerakan nasional untuk menciptakan terbentuknya etika, 
tangunggjawab, dan kepedulian kepada generasi muda dengan membentuk dan mengajarkan karakter yang baik melalui penekanan nilai-nilai universal yang dianut bersama. Beland mendefenisikan pengembangan karakter sebagai sebuah upaya sengaja untuk membantu mengembangkan nilai-nilai kebaikan, moral dan tindakan moral pada generasi muda khususnya di sekolah (Yaumi, 2014). Pembentukan karakter dan pengembangan karakter tersebut dibantu oleh tarian martumba sebagai media yang berpengaruh melalui tanggungjawab dan kerjasama dalam kelompok sehingga nilainilai moralitas terkandung di dalamnya. Dalam memainkan tarian martumba anak akan diberikan tanggungjawab dalam menguasai tarian/gerakan serta menghapalkan syair yang akan dimainkan secara bersamaan. Melalui tarian dan nyanyian tersebut anak akan berproses dalam menampilkan apa yang dia peroleh selama berlatih. Dengan demikian melalui tarian martumba anak akan mendapatkan pendidikan karakter melalui rasa bertanggungjawab, mengembangkan bakat serta berfikir aktif untuk menginterpretasi melaui syair dan tarian martumba.

\section{SIMPULAN}

Memori Budaya menciptakan kembali ingatan masa lalu sebagai proses di mana menjaga kelangsungan budaya kepada generasi selanjutnya. Manusia sebagai pemikul simbol dalam evolusioner memberikan peran penting saat mengenang peristiwa-peristiwa pada masa lampau dalam kegiatan ritual di isi dengan komposisi simbolis dan terus diulang. Lewat budaya yang di regenerasikan untuk mempertahankan identitas budaya maka dapat di transmisikan lewat pengalaman hidup dari iman dan identitas dan sebuah penafsiran budaya untuk terjun ke memori budaya untuk mempertahankan hidup. maka dari itu budaya martumba dapat ditransmisikan menjadi media pendidikan bagi anak untuk mengulang dan mengenang serta mempertahankan budaya untuk mengeksplorasi fenomena ini dengan mengisolasi dan menganalisis konten, transmisi, sumber pemberdayaan, termasuk bagaimana kenangan tersebut diturunkan dari generasi ke generasi.

Permainan tradisional martumba adalah budaya masyarakat Batak yang berawal dari Sibolga yang kemudian berkembang hingga ke masyarakat Batak di Toba, tarian ini diadakan untuk mengingat kenangan di daerah asalnya yang dilakukan oleh pemuda-pemudi serta melestarikan kesenian milik mereka, hingga saat ini perkembangan tarian martumba telah sampai kepada anak-anak yang dipakai oleh Gereja dan sekolah sebagai sarana pendidikan serta membangun kerja sama anak-anak dalam bentuk perlombaan martumba. Tarian martumba ini dimainkan melalui tarian sambil bernyanyi dan bertepuk tangan sehingga daya ingat akan terlatih untuk mengingat syair dinyanyikan secara berulang-ulang selain itu juga memiliki dampak baik bagi kesehatan anak karena gerakan yang dimainkan memakai semua gerak tubuh. Oleh kerana itu tarian martumba dapat menjadi media pendidikan bagi anak, juga bagi pendidikan karakter terhadap anak agar menciptakan dan mengembangkan anakanak di daerah batak Toba menjadi cerdas, keratif, aktif berperadaban yang berlangsung secara terus menerus.

Pengembangan karakter anak melalui permainan tradisional martumba dapat diterapkan dengan menumbuhkan kemampuan bersosialisasi sebagai proses interaksi dengan lingkungannya serta mengajar anak untuk menghargai orang lain, lewat kegiatan tersebut anak juga akan belajar mengurangi egosentrisnya karena berusaha bersaing dengan jujur sehingga dalam hal ini memberi kesempatan kepada anak untuk memahami, meresapi dan memberi arti dalam berelasi bersama dengan anak-anak lainnya. Selain itu juga menumbuhkan nilai 
tanggungjawab kedisiplinan. Anak akan mencintai budayanya sejak dini melalui bahasa, pakaian, tarian yang digunakan saat melalukan tarian martumba sehingga akan mewariskan kepada generasi selanjutnya untuk mencegah punahnya tarian martumba dari masyarakat Batak Toba, yang saat ini mulai terkikis oleh pengaruh perkembangan zaman.

\section{UCAPAN TERIMAKASIH}

Berterimakasih kepada kedua orang tua dan seluruh saudaraku atas semua dukungan moril dan materi selama kuliah di Universitas Kristen Satya Wacana.

\section{DAFTAR PUSTAKA}

Alibi, A., \& Setiawan, J., (2018). Metodologi Penelitian Kualitatif, Jawa Barat: CV Jejak.

Bandi, A.M utama, (2011) Pembentukan karakter anak melalui aktivitas bermaian dalam pendidikan Jasmani, Universitas Negri Yogyakarta. 8: (1), 2-11.

Elita, M., (2018). Keberadaan Tortor Martumba Pada Etnis Batak Toba Di Pesisir Sibolga. Seni Tari. 5: (2), 5-12.

Garmo, J., (2013). Pengembangan Karakter Untuk Anak (Panduan Pendidikan). Jakarta: Kasaint Blanc.
Gusti, T., (2016). Kajian Fungsi, Makna dan Eksistensi Nyanyian Ende Tumba Pada Masyarakat Pangururan Samosir, UNIMED.

Kusumawati, H., (2013). Pendidikan Karakter Lewat Lagu-lagu Anak, Seni dan Pendidikan. Universitas Negeri Yogyakarta. Pendidikan Seni.

Nofrion, (2016). Komunikasi Pendidikan Penerapan Teori dan Konsep Komunikasi Dalam Pembelajaran, Jakarta: Kencana.

Nur, H, (2013), Membangun Karakter Anak Melalui Permainan Tradisional Anak, Universitas Negeri Makasar, Pendidikan Karakater. 3:(1), 90-100.

Prayetty, R., \& Siallagan, M., (2016). Bentuk-Bentuk Tor-tor Martumba Pada Masyarakat Batak Toba di Kabupaten Samosir. UNIMED. 1.

Ernawati, P., (2016). Permainan Tradisional Anak: Salah Satu Kasanah Budaya Yang Perlu di Lestarikan. Jantra: 1(1), 40-50.

Lia, R., Sinaga, V., dkk, (2019). Pengaruh Tari Martumba Terhadap Pengetahuan Kesehatan Reproduksi Remaja di SMA Negri Parlilitan Kecamatan Parlilitan Kabupaten Humbang Hasundutan Tahun 2019, Universitas Negri Medan, Aksara Publik. 3: (4), 217-226.

Rosidatun, (2018). Model Implementasi Pendidikan Karakter. Kulon Gresik: Caramedia Communication.

Rodriguez, J. Ted Fortier, (2007), Memory Culture, Amerika Serikat: University of Texas Press.

Setia, G, \& Sulasman., (2013). Teori-teori Kebudayaan. Bandung: Pustaka Setia.

Yaumi, M., (2014). Pendidikan Karakter Anak. Jakarta: Kencana. 